Tatjana Pišković

Filozofski fakultet Sveučilišta u Zagrebu tatjana.piskovic@gmail.com

iD https://orcid.org/0000-0002-7304-2696

\title{
Hrvatsko rječotvorje na društvenim mrežama
}

Sažetak: U prvome desetljeću 21. stoljeća društvene su mreže postale sastavnim dijelom suvremenoga života, čime se sve više počela potvrđivati društvena orijentiranost aktivnosti korisnika interneta. Otvaranjem profila na društvenim mrežama korisnici interneta prestaju biti pasivni konzumenti sadržaja i informacija koje internet nudi te se pretvaraju u kreatore koji svojim djelatnostima i doprinosima oblikuju dinamičan prostor novih medija. Jedno od najvažnijih područja u koje korisnici društvenih mreža unose mnoge promjene i inovacije svakako su komunikacijske i jezične prakse. Prepoznatljivost društvenih mreža često se zasniva na zadanosti komunikacijskih žanrova dostupnih korisnicima kojima se na taj način određuje kako će međusobno komunicirati. Zato su pred sve polifunkcionalne jezike, pa tako i pred hrvatski, postavljeni mnogi novi zahtjevi na koje odgovaraju brzim punjenjem svojih leksičkih fondova. U radu se prikazuju najplodniji rječotvorni postupci kojima se popunjavaju leksičke praznine u hrvatskome jeziku i oblikuje komunikacijski stil na društvenim mrežama i servisima za trenutačnu razmjenu poruka. Prvi je postupak semantičko posuđivanje iz engleskoga jezika ili tvorba neosemantizama (npr. profil, prijatelj, status, zid, dodati, blokirati, notifikacija), drugi je leksičko posuđivanje (npr. lajkati, postati, šerati, atendati, hejtati, trolati, folover, selfi), a treći tvorba domaćih kratica (pozz, nezz, bmk, jbt, $d n s, f k t$ ). Zbog pojave bogatoga novog leksičkog sloja valjalo bi registrirati niz novih leksičkih jedinica u općim rječnicima hrvatskoga jezika.

Ključne riječi: neosemantizam, leksičko posuđivanje, kratice, društvene mreže, servisi za trenutačnu razmjenu poruka

Bilo bi najpoštenije da pišem o jeziku samo na onoj društvenoj mreži na kojoj imam profil, a to je Facebook. Račun sam otvorila u lipnju 2009. Obično objavljujem statuse o bizarnim situacijama iz svakodnevnog života, a šeram videa s glazbom i duhovitim skečevima 
te linkam tekstove koje smatram zanimljivima i korisnima. Profilnu sam zadnji put promijenila prije sedam mjeseci i za nju dobila 193 lajka, što je pomalo poražavajuće $\mathrm{s}$ obzirom na to da imam 556 prijatelja od kojih je 300 rikvestalo mene, a ostale sam dodala sama. Tri moja najlajkanija posta redom su onaj s viješću da sam postala docentica, potom priča o profesoru s Filozofskog koji mi sugerira promjenu imidža i naposljetku citat iz studentske ankete s opisom moje predavačke kompetencije i stila odijevanja. Imam grižnju savjesti kad sinam poruku na Mesindžeru i ne odgovorim na nju isti čas, ali zapravo me zamara dugotrajno četanje. Nikad ne atendam javne događaje, a samo sam dvaput invajtala svoje prijatelje na takve događaje. Anfrendala sam desetak ljudi koje nisam apruvala i blokirala desetak onih koje sam hejtala, ali sam neke od njih nakon toga stokala s lažnog profila. Iako ću svima reći da su sadržaji na Facebooku banalni i infantilni, samo sam dvaput deaktivirala račun na mjesec dana, a kad mi je račun aktivan, nikad se ne logautam.

Prethodni je odlomak zasićen leksičkim jedinicama nužnima za komunikaciju na Facebooku i o Facebooku. U samo devet mojih rečenica pojavile su se 23 riječi koje su rezultat neologije u širemu smislu: ili su novotvorenice i samim time nove leksičke jedinice u hrvatskome leksikonu ili su već odavna dio hrvatskoga aktivnog leksika, ali su procesom semantičke neologije ili neosemantizma dobile novo značenje. To su redom ove jedinice: profil, račun, status, šerati, linkati, profilna, lajk, prijatelj, rikvestati, dodati, najlajkaniji, post, sinati, mesindžer, četanje, atendati, invajtati, anfrendati, apruvati, blokirati, hejtati, stokati, logautati se. S pomoću tih primjera i onih prikupljenih anketom provedenom među studentima Kroatistike na zagrebačkome Filozofskom fakultetu pokušat ću opisati najplodnije rječotvorne postupke ${ }^{1}$ kojima se popunjavaju leksičke praznine u hrvatskome jeziku i oblikuje komunikacijski stil na društvenim mrežama i servisima za trenutačnu razmjenu poruka.

\footnotetext{
${ }^{1}$ Termin rječotvorje (engl. word formation) razumijevamo isto kao i Ivan Marković u knjizi Uvod u jezičnu morfologiju (Zagreb: Disput, 2013, 54). To znači da ga rabimo kao terminološku nadređenicu koja pokriva i sve mehanizme na koje se odnosi termin rječogradba (engl. word building), dakle kompoziciju, derivaciju, supletivnost, prijevoj, konverziju, reduplikaciju, skraćivanje baze, metatezu i akronimizaciju, ali i sve ostale mehanizme kojima se proizvode nove leksičke jedinice, dakle postupke promjene značenja, neosemantizam, metaforizaciju, metonimizaciju, eponimizaciju i leksičko posuđivanje.
} 


\section{Uvod}

Facebook je društvena mreža osnovana 2004; danas ima više od dvije milijarde korisnika. Otvaranjem profila na Facebooku i drugim društvenim mrežama korisnici interneta prestaju biti pasivni konzumenti sadržaja i informacija koje internet nudi te se pretvaraju u kreatore koji svojim djelatnostima i doprinosima oblikuju dinamični prostor novih medija. ${ }^{2}$ Jedno od najvažnijih područja u koja korisnici društvenih mreža unose mnoge promjene i inovacije svakako su komunikacijske i jezične prakse. Prije pojave interneta jezične su se promjene odvijale sporo jer je trebalo puno više vremena da se prošire jezičnom zajednicom, da se pojave u pisanim tekstovima te da ih jezikoslovci uoče, opišu u znanstvenim radovima, uvrste kao primjere u jezične priručnike i registriraju u rječnicima. Zahvaljujući uporabi na društvenim mrežama, nova leksička jedinica danas može postati globalno poznata za nekoliko sati. Njezina je budućnost jednako neizvjesna kao i prije pojave interneta, pa se može dogoditi da zbog kratkotrajnosti uporabe i pojave mnogobrojnih instant-novotvorbi prođe ispod jezikoslovnih radara i ostane neprimijećena i nezabilježena. Očito je da internetska komunikacija mijenja i dinamiku i logiku jezičnih promjena, ${ }^{3}$ pa se mora mijenjati i jezikoslovni pristup tim fenomenima. Jezikoslovci više ne mogu čekati da cijela jezična zajednica ovjeri neku jezičnu inovaciju i aktivno je uključi u opću uporabu da bi je opisali jer će zbog takve znanstvene skepse i sporosti mnogi primjeri iznimne jezične kreativnosti na internetu ostati nezabilježeni. Mnogi se novi gramatički, leksički i stilski trendovi u internetskoj komunikaciji zbog svoje kratkotrajnosti i vezanosti za specifične skupine govornika ignoriraju kao generacijski ili pomodni kapric. Da bi se današnje jezične promjene mogle navrijeme registrirati i kompetentno interpretirati, svaku jezičnu inovaciju u novim medijima valja opisati čim se uoči; ne može se čekati da dosegne status općeuporabne jedinice jer je takva metodologija zastarjela i neprimjenjiva na opisivanje jezičnih promjena koje se zbivaju pri brzini od 20 megabita u sekundi. Važnost svake pojedinačne ortografske, gramatičke, leksičke ili stilske inovacije moći će se evaluirati tek kad se u jeziku uoči velika promjena koju je usvojila cijela jezična zajednica

\footnotetext{
${ }^{2}$ Philip Seargeant i Caroline Tagg, „The Language of Social Media: Introduction,“ u The Language of Social Media: Identity and Community on the Internet (London: Palgrave Macmillan, 2014), 2.

${ }^{3}$ David Crystal, Internet Linguistics: A Student Guide (London - New York: Routledge, 2011), 57.
} 
i koju su prije toga hranile mnoge takve male, okazionalne i naizgled rubne jezične pojave na društvenim mrežama.

Govornicima hrvatskoga jezika koji se ne koriste društvenim mrežama može se učiniti da se u tim medijima oblikuje posve nov jezični kod prezasićen inovacijama koji im je gotovo neproničan. No istina je da se većina novih jedinica pojavljuje na leksičkoj i ortografskoj razini te da su uglavnom prebrojive, dok je gramatika ${ }^{4}$ vrlo slična onoj izvan elektroničkih medija. ${ }^{5}$ Budući da je leksik najotvorenija jezična klasa, u njemu se najprije očituju i opažaju jezične promjene ${ }^{6}$ i po tome jezik na društvenim mrežama nije nikakva iznimka. Ortografske inovacije i narušavanje grafoloških konvencija oskudniji su postupci od gradbe novih leksičkih jedinica, no vrlo su uočljivi, pa se zbog svoje atraktivnosti nameću i korisnicima društvenih mreža i jezikoslovcima kao iznimno važan aspekt oblikovanja novih diskursnih funkcija internetske komunikacije.

Prepoznatljivost društvenih mreža često se zasniva na zadanosti komunikacijskih žanrova dostupnih korisnicima kojima se na taj način određuje kako će međusobno komunicirati. Facebook primjerice omogućuje objave tekstnoga, vizualnoga, auditivnoga i multimedijskoga

\footnotetext{
${ }^{4}$ Fonologija, morfologija i sintaksa i inače su otpornije na promjene od leksika kao najotvorenijega jezičnog podsustava i pravopisa kao rezultata konvencije. Zato se i na društvenim mrežama promjene na gramatičkoj razini opažaju mnogo rjeđe nego na leksičkoj i pravopisnoj razini. Zapravo, preciznije bi bilo govoriti o gramatičkim posebnostima komunikacije na društvenim mrežama nego o promjenama ili ugrožavanju gramatičke norme u tome mediju komunikacije. Gramatička posebnost jezika na društvenim mrežama prepoznaje se naprimjer u dužini i vrsti rečenica, koje su kratke, jednostavne i često eliptične, odnosno rijetko se nailazi na višestruko složene rečenice. Nadalje ne poštuju se pravila o neobilježenome redu riječi, a rečenice se prekidaju na mjestima koja se ne podudaraju s dovršetkom misli. Između morfoloških dubleta i tripleta biraju se one karakteristične za razgovorni stil. Sve u svemu, čitateljima naviklima na uređene, lektorirane i redigirane tekstove u pisanim medijima prije pojave interneta gramatika na društvenim mrežama može se učiniti pomalo primitivnom i infantilnom. Objave i poruke pišu se brzo, ne provjeravaju se prije objavljivanja ili slanja, pa pisani diskurs često reflektira govoreni iskaz ili misaone procese koji su od njega uvijek neuredniji, razbacaniji. Crystal (Internet Linguistics, 68) takvu gramatičku ležernost uspoređuje s narativnom tehnikom struje svijesti kojom se u romanesknoj prozi nastoji simulirati asocijativni, nekontrolirani tijek misli, osjećaja i dojmova likova. Iz retoričkoga bi se metajezika za to obilježje jezika na društvenim mrežama mogao posuditi termin anakolut. No važno je imati na umu da se gramatika na društvenim mrežama može tako procjenjivati i osuđivati samo iz perspektive normativne gramatike te da se pritom propušta prilika za neposredno promatranje i opisivanje gramatičkih posebnosti novih internetskih žanrova.

${ }^{5}$ Crystal, Internet Linguistics, 57.

${ }^{6}$ Crystal, Internet Linguistics, 58.

${ }^{7}$ Crystal, Internet Linguistics, 61.
} 
sadržaja na zidu, a te objave mogu biti ili javne, ili vidljive korisniku i njegovim (odabranim) prijateljima, ili samo korisniku. Na objave koje su im vidljive korisnici mogu reagirati emotikonom i jezičnim, slikovnim, auditivnim ili multimedijskim komentarom. Osim toga Facebook omogućuje i razmjenu privatnih poruka u realnome vremenu putem aplikacije Messenger (Mesindžer). Jasno je da su objave na zidu filtriranije od privatnih poruka u Messengeru, što znači da svaki od tih načina komunikacije ima svoje zakonitosti. One se primarno oblikuju i ustaljuju u engleskome jeziku, no s vremenom postavke Facebooka postaju sve sofisticiranije, pa se sve njegove funkcije i aktivnosti mogu izreći i opisati i drugim jezicima. Usavršavanje i širenje komunikacijskih mogućnosti u elektroničkim medijima postavlja pred sve polifunkcionalne jezike, pa tako i pred hrvatski, mnoge nove zahtjeve koji u konačnici dovode do oblikovanja novoga diskursnog polja ili novoga diskursnog tipa unutar multimedijskoga diskursnog polja. $\mathrm{U}$ anglofonim se znanstvenim radovima pojavljuje niz termina koji upućuju i na cijelo to polje i na pojedine njegove funkcije (Internet slang, netspeak, textspeak, chatspeak, cyberspeak); ${ }^{8}$ najfrekventniji među njima - netspeak - pojavljuje se i u nekim radovima filologa iz regije, ${ }^{9}$ dok se hrvatska inačica mrežogovor zasad čuje samo u lingvističkim i stilističkim kuloarima kao ironična reakcija na normativna čišćenja internetskoga jezika. U ovome ćemo radu govoriti o multimedijskome diskursu kao o ekvivalentu engleskih termina za računalno, elektronički ili digitalno posredovanu komunikaciju (engl. computer-mediated communication, electronically/ digitally mediated communication, kratice: CMC, EMC, DMC). Unutar toga diskursnog polja razlikovat ćemo komunikaciju na društvenim mrežama od privatne komunikacije putem servisa za trenutačnu razmjenu poruka (engl. instant messaging services).

Budući da su leksičke i ortografske inovacije najuočljiviji simptomi oblikovanja novih diskursnih vrsta u multimedijskome diskursnom polju hrvatskoga jezika, u ovome ćemo radu prikazati dva rječotvorna postupka kojima se popunjavaju leksičke praznine u komunikaciji na društvenim mrežama i jedan ortografski postupak koji postaje konven-

\footnotetext{
${ }^{8}$ David Crystal, A Glossary of Netspeak and Textspeak (Edinburgh: Edinburgh University Press, 2004). Usp. i Crystal, Internet Linguistics, 2.

9 Sanel Hadžiahmetović Jurida, „Some distinctive lexical features of Netspeak,“ Jezikoslovlje, sv. 8, br. 2 (2007): 193-210; Jelena Redli, „Inovacije u jeziku mladih na društvenim mrežama,“ResearchGate (2018), pristupljeno 7. studenog 2019, https://www.researchgate.net/ publication/329587163_INOVACIJE_U_JEZIKU_MLADIH_NA_DRUSTVENIM_MREZAMA.
} 
cija u razmjeni privatnih poruka na Messengeru i ostalim servisima za trenutačnu razmjenu poruka (WhatsApp, Viber, Snapchat, Skype, Signal).

\section{Popunjavanje leksičkih praznina}

Leksičke su aktivnosti na društvenim mrežama vrlo dinamične, kreativne i raznovrsne. Očito je da se oblikuje nov leksički sloj vezan za to komunikacijsko polje, pri čemu se stvara dojam kako se taj leksički fond puni tolikom brzinom da se nameće kao svojevrstan paraleksikon koji subvertira općeuporabni hrvatski leksik. No Crystal ističe da je golema većina leksičkih inovacija na internetu okazionalna i da je broj aktivnih internetskih neologizama mnogo manji od onih nastalih u istome razdoblju u stručnim terminologijama (primjerice u botaničkoj ili kemijskoj terminologiji). ${ }^{10}$ Stoga je utjecaj leksičkih inovacija s društvenih mreža na narav ukupnoga leksika nekog jezika još uvijek malen. U hrvatskome se jeziku doista pojavila skupina novih leksičkih jedinica, kao što se to događa uvijek kad se pojavi nova domena znanja ili ljudske aktivnosti, a dva se rječotvorna postupka mogu izdvojiti kao posebno produktivna u njihovu oblikovanju: neosemantizam i leksičko posuđivanje.

\subsection{Neosemantizam}

Neosemantizam se obično određuje kao dodavanje novoga značenja postojećemu leksemu, ${ }^{11}$ što je preširoka i preopćenita definicija jer kolidira s dvama kanonskim leksičkim mehanizmima koji omogućuju polisemni rast leksema, odnosno s leksičkom metaforom i leksičkom metonimijom, a pritom zanemaruje kontaktnu narav neosemantizma. Štoviše, takve definicije ustoličuju neosemantizam kao krovni termin za sve mehanizme proširivanja značenja riječi, što nije točno jer se neosemantizam uvijek realizira nekim od leksičkih mehanizama polisemije, najčešće leksičkom metaforom, ali nije svaka leksička metafora motivirana kontaktnim procesima. Preciznija su i bolja određenja neosemantizma kao semantičkoga posuđivanja koje podrazumijeva da jezik

\footnotetext{
${ }^{10}$ Crystal, Internet Linguistics, 60.

${ }^{11}$ Ruth Vatvedt Fjeld i Lars Nygaard, „Lexical Neography in Modern Norwegian,“ u Exploring Newspaper Language. Using the Web to Create and Investigate a Large Corpus of Modern Norwegian, ur. Gisle Andersen (Amsterdam - Philadelphia: John Benjamins Publishing Company, 2012), 224; Fred W. Riggs, „Terminology and Lexicography: Their Complementarity,“ International Journal of Lexicography, sv. 2, br. 2 (1989): 94.
} 
primatelj posuđuje iz jezika davatelja sämo značenje nekog leksema i pridružuje ga ekvivalentnomu domaćem leksemu dodajući mu tako novo značenje. ${ }^{12} \mathrm{U}$ skladu s takvim tumačenjem neosemantizam označava polisemni rast već postojećega leksema, samo što poticaj za taj rast dolazi iz stranoga jezika gdje je proces dodavanja novoga značenja već postojećemu leksemu dovršen, leksikaliziran i prihvaćen u jezičnoj zajednici. Jedan od najčešćih primjera kojim se neosemantizam ilustrirao pri uvođenju toga termina u kroatističku literaturu bio je leksem MIš koji je pod utjecajem engleskoga jezika uz postojeća značenja 'mali glodavac šiljaste njuške i duga repa', 'dječak' i 'muški spolni organ' razvio novo značenje, 'vanjska računalna komponenta koja upravlja kursorom (strelicom ili sl.) na ekranu'. Dakle kad se u izvanjezičnome svijetu pojavio nov predmet koji je trebalo imenovati, nije se u hrvatskome jeziku tvorila posve nova riječ, nego se već postojećoj riječi pridružilo novo značenje na temelju leksičke metafore, i to pod utjecajem tako provedena postupka u engleskome jeziku. Riggs tvrdi da mnogi terminolozi pri osmišljavanju termina za nove koncepte radije biraju neosemantizme nego neologizme. ${ }^{13}$ Naime neologizmi su uz tuđice najčešća meta purističkih sankcija, a ne može se predvidjeti ni kako će jezična zajednica reagirati na njih i hoće li ih pripustiti u opću uporabu. Zato terminolozi drže da svoje prijedloge manje izlažu ismijavanju i odbacivanju ako iskoriste već postojeći leksem i dodaju mu novo značenje nego ako skuju posve novu riječ. Neosemantizam je stoga uobičajen i čest leksički mehanizam uspostavljanja novih značenja leksema i držat ćemo ga svojevrsnim hibridom drugih dvaju mehanizama za popunjavanje leksičkih praznina u jeziku: leksičkoga posuđivanja i leksičke metafore.

Neosemantizmi se jednostavno nameću kao mehanizam popunjavanja praznina u onom sloju hrvatskoga leksika koji se odnosi na komunikaciju na društvenim mrežama. Naime izvorni je jezik Facebooka engleski, a jedan od načina popunjavanja engleskoga leksičkog fonda na toj je društvenoj mreži proširivanje značenja već postojećih leksema. Dakle novi koncepti vezani za Facebook u engleskome se jeziku često leksikaliziraju iskorištavanjem postojećih leksema, a ne tvorbom posve novih leksičkih jedinica. Hrvatski jezik imitira taj obrazac pronalazeći engleskim riječima domaće ekvivalente i dodajući im isto značenje koje je dodano engleskomu modelu.

\footnotetext{
${ }_{12}$ Marko Samardžija, Hrvatski jezik 4 (Zagreb: Školska knjiga, 2001), 54; Marija Turk, „Razumljivost i stilske značajke kalkova,“ Fluminensia, sv. 15, br. 1 (2003): 11.

${ }^{13}$ Riggs, ,Terminology and Lexicography,“ 98.
} 
Kao primjere neosemantizama u hrvatskome jeziku nastalih na Facebooku navest ćemo leksičke jedinice iz moje uvodne priče koje su po uzoru na engleske modele proširile svoja značenja: prijatelj, profil, status, dodati, blokirati, račun. Svi su ti leksemi polisemni i registrirani su u hrvatskim jednojezičnim rječnicima, ${ }^{14}$ no ni u jednome od njih ne opisuju se ona njihova značenja koja su u novije vrijeme uspostavljena za komunikaciju na društvenim mrežama. Štoviše, ni u jednome od tih rječnika ne postoji natuknica FACEBOOK, a samo se u VRH-u uz natuknicu MREŽA u sintagmatskoj odrednici pojavljuje podunosak društvena mreža sa značenjem 'vrsta internetskog servisa, koji se najčešće javlja u obliku platforme, prozora ili web-stranice; internetski prostor koji služi za međusobno povezivanje korisnika'. Neka od opisanih značenja spomenutih leksema nisu više aktualna i odavna su prešla u pasivni leksik, što ukazuje na to da je leksikografski mar više na strani pasiviziranih leksičkih značenja nego onih inovativnih. Drugim riječima, značenje koje je jednom registrirano u općemu rječniku teško se iz njega briše, dok nova značenja prolaze dugotrajnu uporabnu kušnju prije nego što dobiju priliku da ih rječnici registriraju. Primjer je za to leksem PRIJATELJ kojemu je u VRH-u opisano pet značenja; uz primarno značenje 'blizak poznanik s kojim se u druženju njeguju poštovanje, povjerenje i ljubav' navode se i četiri sekundarna, izvedena značenja: 2. 'ljubavnik', 3. 'otac jednoga od bračnih drugova prema ocu drugoga', 4. 'poklonik, zaštitnik čega', 5. 'fam. konvencionalno oslovljavanje pri obraćanju kojim se želi naglasiti bliskost'. Značenja su gotovo navlas isto opisana u Velikome Aniću i na HJP-u; nedostaje samo značenje 'ljubavnik', a značenje 'otac jednoga od bračnih drugova prema ocu drugoga' kvalifikatorom etnol. usmjereno je u posebnu domenu primjene. To značenje nije općepoznato ni općeuporabno; vjerojatno se pojavljuje samo u nekim hrvatskim regiolektima i zbog toga bi mu mjesto bilo u posebnome, a ne u općemu rječniku. Značenje koje je taj leksem dobio na Facebooku, 'osoba s kojom je korisnik povezan na društvenoj mreži', aktualno je, frekventno i prepoznatljivo na razini opće uporabe već više od petnaest godina, pa svoje mjesto u rječniku zaslužuje više od spomenuta značenja iz domene etnologije, kao i od

\footnotetext{
${ }^{14}$ Za provjeru leksikografskih definicija korišteni su opći jednojezični hrvatski rječnici objavljeni nakon pokretanja Facebooka: Veliki rječnik hrvatskoga jezika Vladimira Anića = Veliki Anić (Zagreb: Novi Liber, 2005) i Veliki rječnik hrvatskoga standardnog jezika = VRH (Zagreb: Školska knjiga, 2015), kao i Hrvatski jezični portal = HJP (http://hjp.znanje. hr/index.php?show=main) koji je na internetu dostupan od 2006, ali dopušta stalna osvježavanja.
} 
drugoga značenja opisana uz podunosak kućni prijatelj ('ljubavnik žene, domaćice kuće'). Iako ističe da je određivanje primarnoga značenja polisemne riječi prema procjeni hoće li to značenje prvo pasti na pamet izvornomu govorniku subjektivan i „čisto impresionistički“ postupak, Zgusta usvaja tu procjenu kao relevantan kriterij za razlučivanje primarnoga od sekundarnih značenja polisemne riječi. ${ }^{15}$ Taj se kriterij može primijeniti i pri rangiranju sekundarnih značenja, pa će se viši redni broj u leksikografskoj jedinici dodijeliti frekventnijemu značenju. Prema tomu kriteriju stotinu studenata Kroatistike u Zagrebu značenje imenice prijatelj vezano za Facebook ('osoba s kojom je korisnik povezan na društvenoj mreži') odredilo je kao drugo po uporabnoj frekventnosti, odnosno prema njihovoj je procjeni to značenje odmah iza značenja 'blizak poznanik s kojim se u druženju njeguju poštovanje, povjerenje i ljubav'. ${ }^{16} \mathrm{~S}$ obzirom na to da su svi ispitanici rođeni između 1996. i 2000. godine, jasno je da su značenje 'osoba s kojom smo povezani na društvenoj mreži' unijeli u svoj mentalni leksikon gotovo u isto vrijeme kad i značenje 'blizak poznanik', pa rezultati ankete nisu iznenađujući. No usuđujemo se pretpostaviti da bismo takve rezultate dobili od svih korisnika Facebooka, bez obzira na to kada su rođeni.

Leksem status ima tri opisana značenja u VRH-u, Velikome Aniću i na HJP-u: 'posebni ili osobni položaj koji je reguliran zakonima, propisima ili običajima', 'razg. položaj u društvu' i 'stanje stvari;

\footnotetext{
${ }^{15}$ Ladislav Zgusta, Priručnik leksikografije (Sarajevo: Svjetlost, 1991), 66.

${ }^{16}$ Anketa je provedena akademske godine 2018/2019. među studentima druge i četvrte godine Kroatistike Filozofskoga fakulteta Sveučilišta u Zagrebu na kolegijima Hrvatski standardni jezik - Morfologija i Hrvatska leksikologija. Anketni je upitnik ispunilo 100 studenata, a sastojao se od triju dijelova. U prvome sam dijelu studentima ponudila imenicu prijatelj, pet značenja opisanih u VRH-u i značenje vezano za uporabu na Facebooku te tražila od njih da ponuđena značenja rangiraju s obzirom na to koliko ih često rabe. Značenja su na anketnome listiću bila odvojena u zasebne odlomke ispred kojih su studenti morali upisati redne brojeve od 1. (za značenje koje najčešće rabe) do 6. (za značenje koje najrjeđe rabe ili ga uopće ne rabe). Nisam poštivala redoslijed navođenja značenja u VRH-u, nego sam ih poredala ovako: 'ljubavnik', 'poklonik, zaštitnik čega', 'blizak poznanik s kojim se u druženju njeguju poštovanje, povjerenje i ljubav', 'osoba s kojom je korisnik povezan na društvenoj mreži', 'otac jednoga od bračnih drugova prema ocu drugoga', 'konvencionalno oslovljavanje pri obraćanju, prijatelju'. Konačan rezultat ankete bio je ovakav: kao primarno značenje imenice prijatelj 100 studenata navelo je 'blizak poznanik s kojim se u druženju njeguju poštovanje, povjerenje i ljubav'; kao drugo značenje 100 studenata navelo je 'osoba s kojom je korisnik povezan na društvenoj mreži'; kao treće značenje 98 studenata istaknulo je 'poklonik, zaštitnik čega', a dvoje 'konvencionalno oslovljavanje pri obraćanju', odnosno kao četvrto značenje 98 studenata navelo je 'konvencionalno oslovljavanje pri obraćanju', a dvoje 'poklonik, zaštitnik čega'. Svih 100 studenata na peto je mjesto stavilo značenje 'ljubavnik', a na šesto 'otac jednoga od bračnih drugova prema ocu drugoga'. O drugim dvama dijelovima anketnoga upitnika bit će više riječi u sljedećim poglavljima.
} 
situacija u kojoj se što nalazi'. Valjalo bi mu dodati i četvrto koje se odnosi na ponajvažniju aktivnost na Facebooku: 'objava na društvenoj mreži u kojoj korisnik izražava svoja stajališta ili prenosi obavijesti'. U VRH-u se opisuje pet značenja leksema PROFIL (1. 'lice gledano sa strane', 2. 'pogled sa strane', 3. 'arhit. vertikalni, uzdužni ili poprečni presjek građevine ili pojedinoga arhitektonskog elementa', 4. 'tehn. poprečni ili uzdužni presjek čega', 5. 'skup svojstava kojima se tko ili što razlikuje od drugoga') ${ }^{17}$ valjalo bi mu dodati šesto: 'podaci kojima korisnik oblikuje svoj korisnički račun na društvenoj mreži'. Leksemu DODATI opisana su u VRH-u četiri značenja: 1. a. 'uručiti, pružiti komu što, predati što iz ruke u ruku', b. 'bacajući predati komu što', 2. 'uvećati što u odnosu na već postojeću masu, volumen ili broj', 3. 'staviti još čega u što', 4. 'reći nakon što se već nešto reklo'. ${ }^{18}$ Treba mu dodati i peto: 'sprijateljiti se s novom osobom na društvenoj mreži; uvrstiti nov kontakt na listu prijatelja'. Leksem BLOKIRATI ima sedam opisanih značenja: 1. 'stvoriti/stvarati fizičke prepreke za prolaz, normalno odvijanje čega', 2. 'onemogućiti/onemogućivati koga u čemu', 3. 'službenom, sudskom odlukom onemogućiti koga da raspolaže svojim sredstvima', 4. 'spriječiti čiji rad, učiniti da što ne radi ili da se zaustavi', 5. ‘šp. zaustaviti napadača postavljanjem tijela ili sprečavanjem udarca', 6. 'med. onemogućiti/ onemogućivati razvoj čega negativnog u čovječjem organizmu', 7. 'pren. izgubiti sposobnost normalnog reagiranja'. ${ }^{19}$ Primjerima navedenima uz drugo značenje valjalo bi dodati još jedan kojim bi se specificiralo značenje vezano za društvene mreže: 'onemogućiti određenom korisniku društvene mreže da komunicira s drugim korisnikom'. Od svih primjera neosemantizma spomenutih u uvodnoj priči leksem RAČUN ima najbogatiju polisemnu strukturu; u VRH-u ima čak osam opisanih značenja: 1. 'operacija ili niz operacija koje se odnose na kombinacije brojeva ili na veličine, postupak kojim se računa, odnosno kojim se rješavaju aritmetički problemi', 2. 'potvrda o plaćenoj usluzi ili robi', 3. 'potvrda o novčanom iznosu koji treba platiti', 4. 'sredstva za obavljanje čega, proračun', 5. 'stanje primitaka i izdataka, evidencija o dugovanjima i potraživanjima; obračun', 6. 'sastavni dio naziva u knjigovodstvu

\footnotetext{
${ }^{17}$ Sva popisana značenja leksema PROFIL opisana su i u Velikome Aniću i na HJP-u, samo su drukčije poredana. Ta dva rječnika bilježe jedno značenje koje nije registrirano u VRH-u: 'tehn. proizvod od metala karakteristična presjeka'.

${ }^{18}$ U drugima dvama rječnicima nije zabilježeno samo jedno od značenja opisanih u VRH-u ('staviti još čega u što').

${ }^{19}$ U Velikome Aniću i na HJP-u opisano je pet značenja (četvrto ima dva podznačenja); treće i peto značenje iz VRH-a nemaju svoje ekvivalente u spomenutim dvama rječnicima.
} 
i bankarskom poslovanju, ugovor koji banka sklapa s korisnicima svojih usluga te pod tim brojem vodi njihov novčani promet', 7. 'zarada koju tko ima u čemu', 8. 'ono što se koga ili čega tiče, ono o komu ili o čemu je riječ'. ${ }^{20}$ Svaka osoba koja se želi služiti internetom mora sklopiti ugovor s određenom tvrtkom koja osigurava tu uslugu. Taj ugovor zove se račun i danas označava niz ugovorenih odnosa s različitim servisima, tvrtkama i subjektima koji pružaju različite internetske usluge; podrazumijeva i ugovor s društvenim mrežama koje korisniku u zamjenu za osobne podatke daju priliku da na njima kreira svoj profil i koristi se njihovim uslugama. Šesto značenje u VRH-u valjalo bi raslojiti na više podznačenja kojima bi se obuhvatila sva „ugovorna“ značenja leksema RAČUN.

Osim neosemantizama spomenutih u uvodnoj priči valja spomenuti još neke frekventnije i nužne za komunikaciju na Facebooku. Leksem ZID razvija novo značenje 'prostor na internetskoj stranici društvene mreže na kojem korisnik i njegovi prijatelji objavljuju različite sadržaje', a leksem NOTIFIKACIJA značenje 'ikona i/ili zvuk na elektroničkom uređaju koji korisnika obavještava o novostima na korisničkom računu'. Uz leksem CRTA valjalo bi kao podunosak u rječnike uvrstiti sintagmu vremenska crta sa značenjem 'ukupnost kronološki poredanih objava na određenoj društvenoj mreži', a uz leksem FOTOGRAFIJA sintagme naslovna fotografija i profilna fotografija kao posebne vrste vizualne identifikacije korisničkoga profila.

Budući da u hrvatskoj leksikografskoj praksi nije običaj da se objavljuju godišnji (ili periodični) dodaci velikim jednojezičnim rječnicima, neka se značenja nikada ne probiju u te autoritativne knjige koje bi im osigurale vidljivost i primjerenu leksikografsku obradu. Jednostavno ostanu u vakuumu između različitih izdanja već postojećih rječnika ili ispod radara onih novih. Zato iznenađuje slabo ili nikakvo ažuriranje HJP-a jer mu medij u kojemu postoji omogućuje stalno usavršavanje i osvježavanje. Jedan od primjera zapuštenosti toga internetskog rječnika jest obrada leksema PORUKA kojemu su opisana samo dva značenja: 'obavijest, vijest, novost, sadržaj koji se po kome prenosi ili šalje' i 'pren. osnovna misao koju autor nekog umjetničkog djela želi prenijeti'. Nema naznake da postoje poruke koje se ne šalju po drugim ljudima (ili golubovima), nego putem računala i mobitela. Iako se na HJP-u opisuju značenja i takvih poruka, na njih se ne upućuje $\mathrm{s}$ te

\footnotetext{
${ }^{20}$ U drugim dvama rječnicima opisano je sedam značenja, no pribroje li im se neki primjeri iz frazeološke odrednice, može se zaključiti da su opisana ista značenja kao i u VRH-u.
} 
leksikografske natuknice, nego ih treba tražiti pod natuknicama SMS i e-mail. U VRH-u se primarno značenje leksema PORUKA ('ono što se komu prenosi ili šalje') oprimjeruje najčešćim vrstama poruka koje se danas razmjenjuju, elektroničkom porukom i sms-porukom, što je bolja leksikografska praksa od one na HJP-u.

$\mathrm{S}$ obzirom na to da se u definicijama većine spomenutih neosemantizama pojavljuje sintagma „društvena mreža“, jasno je da se taj medij može držati novom domenom primjene leksičkoga značenja, ${ }^{21}$ što bi u rječnicima valjalo indicirati posebnim kvalifikatorom. Naime osim što kvalifikatori signaliziraju različite aspekte konotativnih značenja leksema (arh., augm., dem., dijal., eufem., fam., hip., knjiš., pejor., podr., razg., reg., vulg., žarg. itd.), njihova je funkcija i to da određena značenja usmjeravaju u posebne, uglavnom stručne, domene primjene (med., prav., prom., arhit., astron., biol., bot., film., kem., knjiž., pov., psih., stom. itd.). Budući da u rječnicima postoji kvalifikator int. koji upućuje na leksička značenja vezana za internet, njime se može obuhvatiti i značenje vezano za društvene mreže kako bi se izbjeglo umnožavanje poddomena i uvođenje novih kvalifikatora.

\subsection{Leksičko posuđivanje}

U komunikaciji na društvenim mrežama i servisima za trenutačnu razmjenu poruka u hrvatski jezik ulaze isključivo leksičke jedinice iz engleskoga jezika, što je u skladu sa statusom engleskoga kao globalnoga kontaktnog jezika ${ }^{22}$ i predodžbom da je u suvremenim kontaktnim procesima jedini jezik davatelj engleski, a svi su ostali jezici primatelji. Kada u hrvatski kao jezik primatelj uđe engleski leksem kao model, podvrgava se fonološkoj, morfološkoj, sintaktičkoj, ortografskoj i semantičkoj prilagodbi težeći statusu posuđenice ili replike. ${ }^{23}$ Ishodi adaptacijskih procesa engleskih modela u komunikaciji na društvenim mrežama i servisima za trenutačnu razmjenu poruka različiti su i neujednačeni, a o razlozima nepredvidljivih rezultata oblikovanja hrvatske replike može se zasad samo nagađati. Općenito govoreći, razlike u prilagodbi engleskih leksičkih jedinica bilo kojemu jeziku primatelju u spomenutome mediju ovise ponajviše o govornicima ili

\footnotetext{
${ }^{21}$ Zgusta, Priručnik leksikografije, 46-50.

${ }^{22}$ Manfred Görlach, English in Europe (Oxford: Oxford University Press, 2002), passim.

${ }^{23}$ Rudolf Filipović, Teorija jezika u kontaktu. Uvod u lingvistiku jezičnih dodira (Zagreb: Jugoslavenska akademija znanosti i umjetnosti - Školska knjiga, 1986); Rudolf Filipović, Anglicizmi u hrvatskom ili srpskom jeziku: porijeklo, razvoj, značenje (Zagreb: Jugoslavenska akademija znanosti i umjetnosti - Školska knjiga, 1990).
} 
korisnicima tih medija, o njihovoj dobi, profesiji, spolu, obrazovanju, kompetencijskoj razini, ${ }^{24}$ stavovima o engleskome jeziku, identitetu društvene skupine kojoj pripadaju, ${ }^{25}$ privatnosti/javnosti komunikacije, primatelju poruke, brzini oblikovanja poruke itd. S obzirom na to da utjecaj sociolingvističkih čimbenika na adaptacijske procese anglizama u elektroničkoj komunikaciji na hrvatskome jeziku tek treba istražiti, opisati i potkrijepiti statističkim podacima, zadržat ćemo se na prikazu i kontaktološkoj analizi konkretnih primjera prikupljenih anketom. ${ }^{26}$

Već se iz moje uvodne priče vidi da među anglizmima u promatranome komunikacijskom mediju prevladavaju glagoli: šerati '(po)dijeliti sadržaj s drugim korisnicima društvene mreže', linkati 'objaviti/objavljivati poveznicu na određeni internetski sadržaj', rikvestati '(po)slati zahtjev za prijateljstvo na Facebooku', atendati 'potvrditi/ potvrđivati dolazak na neki događaj pritiskom na ikonu Dolazim ispod objave tog događaja', invajtati 'pozvati/pozivati prijatelje na društvenoj mreži na određenu aktivnost', anfrendati 'prekinuti prijateljstvo na Facebooku', apruvati 'odobriti/odobravati čiji postupak', hejtati 'ne simpatizirati koga', stokati/stalkati 'uhoditi koga preko društvenih mreža', sinati/seenati 'vidjeti poruku na servisu za trenutačnu razmjenu poruka', logautati se 'odjaviti se s kakve mrežne stranice', chatati/četati 'dopisivati se putem servisa za trenutačnu razmjenu poruka'. Svi su glagoli potvrđeni i u studentskoj anketi, a valja im pridružiti još neke frekventnije primjere koje su studenti naveli: lajkati '1. iskazati/iskazivati svoje odobravanje koga ili čega preko društvenih mreža, pokazati/ pokazivati komentarom ili pritiskom na za to predviđeno mjesto ispod kakva teksta ili fotografije da se komu tko ili što sviđa odnosno da ga podupire u čemu; 2. odobriti/odobravati, biti sklon komu ili čemu, složiti se s čime', guglati 'pretraživati internet s pomoću tražilice Google',

\footnotetext{
${ }^{24}$ Anja Nikolić-Hoyt, „Hrvatski u dodiru s engleskim jezikom,“ u Hrvatski jezik u dodiru s europskim jezicima: prilagodba posuđenica Lelije Sočanac, Orsolye Žagar-Szentesi, Dragice Dragičević, Ljube Dabo-Denegri, Antice Menac i Anje Nikolić-Hoyt (Zagreb: Nakladni zavod Globus, 2005), 184, 190.

${ }^{25}$ Ignacio M. Palacios Martínez i José A. Sánchez Fajardo, „Introduction: Gaining Insights into English as a Contact Language and Its Diffusion," Alicante Journal of English Studies, sv. 30 (2017): 5 .

${ }^{26}$ Struktura ispitanika i prvo pitanje u anketi opisani su u 16. fusnoti. U drugome dijelu ankete ispitanici su morali navesti sve anglizme koje rabe ili oni ili njihovi adresati u komunikaciji na društvenim mrežama i servisima za trenutačnu razmjenu poruka, a u trećemu sve kratice koje rabe na servisima za trenutačnu razmjenu poruka. O kraticama će više riječi biti u sljedećemu poglavlju. Važno je napomenuti da vrijeme ispunjavanja anketnoga upitnika nije bilo ograničeno, pa su mi studenti predavali ispunjene upitnike tijekom cijele akademske godine i naknadno mi se javljali s dopunama i novim primjerima.
} 
folovati/followati 'pratiti koga na društvenoj mreži', kliknuti '1. (što) pritisnuti tipku miša; izabrati ikonu na ekranu elektroničkog uređaja; 2. (s kim) povezati se s nekim, sprijateljiti se, zaljubiti se', apdejtati '1. (što) osvježiti/osvježavati, ažurirati koji sadržaj; 2. (koga) informirati o novostima', postati/poustati 'objaviti/objavljivati sadržaj na društvenoj mreži', trolati 'provocirati koga u raspravi na društvenoj mreži ili u usmenoj komunikaciji', skrolati 'pomaknuti/pomicati pokazivač kroz tekst ili programski kod prikazan na ekranu', vocapati 'dopisivati se na servisu WhatsApp', ulogirati se, loginati se 'prijaviti se svojim korisničkim imenom na kakvu mrežnu stranicu', odlogirati se 'odjaviti se s kakve mrežne stranice', dilitati '(o)brisati sadržaj na društvenoj mreži', čekirati 'provjeriti/provjeravati', kenslati '1. otkazati/otkazivati internetsku narudžbu, 2. povući/povlačiti objavu s društvene mreže'.

Analiza fonološke adaptacije engleskih modela prema teoriji jezičnih dodira Rudolfa Filipovića podrazumijeva detaljnu analizu supstitucije fonema engleskoga modela fonemima hrvatskoga jezika u replici. ${ }^{27}$ Preduvjet za procjenu o kojemu se tipu fonološke adaptacije svakoga pojedinačnog engleskog fonema radi (o nultoj, kompromisnoj ili slobodnoj transfonemizaciji) jest kontrastivna analiza fonoloških sustava engleskoga i hrvatskoga jezika. ${ }^{28}$ Nultu transfonemizaciju prolaze engleski fonemi koji se po mjestu i načinu artikulacije u potpunosti ili gotovo u potpunosti podudaraju s ekvivalentnim hrvatskim fonemima. ${ }^{29}$ To su primjerice ovi: /a/ (lajkati), / / / apdejtati), /E/ (atendati, rikvestati, anfrendati), /i/ (sinati, dilitati), /u/ (apruvati, guglati), /ty/ (čekirati, četati), /f/ (folovati, anfrendati), /g/ (guglati), /k/ (kliknuti, kenslati, rikvestati, stokati), /1/ (logirati se, lajkati, loginati se, odlogirati se, logautati se, dilitati, folovati), /p/ (postati, vocapati), /J/ (̌̌erati). Kompromisnu transfonemizaciju prolaze engleski fonemi koji se od hrvatskih zamjena razlikuju bilo po stupnju otvorenosti (vokali) bilo po mjestu artikulacije (suglasnici): /æ/ (vocapati), /I/ (invajtati, linkati), /o/ (stokati, loginati se, logautati se), /v/ (logautati se), /d/ (dilitati, atendati), /h/ (hejtati), /n/

\footnotetext{
${ }^{27}$ Filipović, Teorija jezika u kontaktu; Filipović, Anglicizmi u hrvatskom ili srpskom jeziku; usp. i Nikolić-Hoyt, „Hrvatski u dodiru s engleskim jezikom“.

${ }^{28}$ Nikolić-Hoyt, „Hrvatski u dodiru s engleskim jezikom,“ 186.

${ }^{29}$ Nikolić-Hoyt („Hrvatski u dodiru s engleskim jezikom,“ 182) ističe da se u analizi fonološke adaptacije zanemaruju akustička svojstva glasova. Zato se za neke foneme kaže da su „gotovo u potpunosti podudarni“ i pripisuje im se nulta transfonemizacija iako se prema IPA-i bilježe različitim simbolima, a za druge se tvrdi da su „slični“ i da prolaze kroz kompromisnu transfonemizaciju iako se prema IPA-i bilježe identičnim simbolima. No autorica je jasno argumentirala razloge takva tumačenja prilagodbe engleskih fonema hrvatskima, pa u prikazu transfonemizacije glagola u ovome poglavlju slijedimo njezin opis.
} 
(atendati, kenslati, sinati), /r/ (rikvestati, anfrendati, šerati, skrolati), /s/ (sinati, stokati, skrolati, rikvestati), /t/ (trolati, atendati), /v/ (invajtati, apruvati). Slobodnu transfonemizaciju prolaze engleski fonemi koji ne postoje u hrvatskome jeziku, pa se fonološki oblik replike formira prema ortografiji modela, prema izgovoru modela ili kombinacijom tih dvaju postupaka. ${ }^{30} \mathrm{U}$ primjerima iz našega korpusa slobodno su transfonemizirani primjerice ovi engleski fonemi: /p/ (folovati, vocapati), //2/ (atendati, apruvati), /I/ (invajtati), /eI/ (hejtati), /عə/ (̌̌erati), /ov/ (folovati, postati, skrolati, trolati), /W/ (vocapati).

Ortografija navedenih hrvatskih glagolskih replika uglavnom se formira nakon završene transfonemizacije, odnosno nakon što je ustanovljen način na koji će se engleski model izgovarati hrvatskim glasovima. Većini se glagola iz našega korpusa ortografija formira prema izgovoru replike (vocapati, šerati, lajkati, guglati, logautati se itd.); postoji samo nekoliko primjera ortografskih dubleta koje su rezultat kombinacije dvaju različitih načina ortografske prilagodbe. Prvo, neki se glagoli bilježe i prema izgovoru hrvatske replike (postati) i prema izgovoru engleskoga modela (poustati); drugo, neki se glagoli bilježe i prema izgovoru hrvatske replike (folovati, stokati, sinati, četati) i prema izvornoj ortografiji modela (followati, stalkati, seenati, chatati). U potonjoj skupini glagola valja izdvojiti nekoliko primjera kojima se ortografski lik oblikuje i prema izgovoru hrvatske replike (dilitati, čekirati, šerati) i kombinacijom izvorne ortografije modela u prvome dijelu riječi i izgovora replike u drugome dijelu riječi (deletati (engl. delete), chekirati (engl. check), sherati (engl. share)). ${ }^{31}$

Svi glagoli prolaze potpunu transmorfemizaciju jer se engleskoj bazi dodaju i hrvatski tematski sufiks i hrvatski gramatički morf, odnosno, prema Filipovićevoj teoriji, engleskomu slobodnom morfemu dodaju se hrvatski vezani morfemi. Golema većina novih glagola posuđenih

\footnotetext{
${ }^{30}$ Nikolić-Hoyt, „Hrvatski u dodiru s engleskim jezikom,“" 188.

${ }^{31}$ Iako smo obećali da nećemo ulaziti u istraživanje sociolingvističkih čimbenika koji možda utječu na pojavu dvostrukih ishoda adaptacijskih procesa, ipak ne možemo prešutjeti komentare koje su studenti Kroatistike samoinicijativno upisivali u anketne upitnike. Naime naglašavali su da oni sami anglizme pišu onako kako ih izgovaraju hrvatskim glasovima, ali da neki njihovi adresati (koji ne studiraju kroatistiku) baze nekih anglizama pišu onako kako se pišu u engleskome jeziku. Nikolić-Hoyt („Hrvatski u dodiru s engleskim jezikom,“ 190) takvu praksu argumentira sociolingvističkim razlozima: „U novije pak vrijeme, zahvaljujući porastu broja govornika engleskog kao stranog jezika kao i njihove kompetencijske razine, znatan broj novih anglicizama zadržava ortografski oblik modela, to jest engleskoga. Tomu, dakako, pridonosi i prestižan utjecaj engleskog jezika i kulture u suvremenom svijetu.“
} 
iz engleskoga jezika ulazi u 1 . razred V. vrste, ${ }^{32}$ odnosno i u infinitivu i u prezentu imaju tematski sufiks $-a$ - (̌ser-a-ti - šer-a-m, lajk-a-ti lajk-a-m, hejt-a-ti - hejt-a-m) ili -ira- (ček-ira-ti - ček-ira-m, log-ira-ti se - log-ira-m se). Inklinacija glagolskih posuđenica toj klasi samo potvrđuje njezinu otvorenost te jednostavnost i predvidljivost njezinih paradigmatskih obrazaca. Jedini primjer iz našega korpusa koji se potpuno odmetnuo iz te klase jest glagol kliknuti koji se mijenja po II. vrsti (klik-nu-ti, klik-ne-m). Glagol folovati može se mijenjati i po V. vrsti (folov-a-ti-folov-a-m) i po VI. vrsti (fol-ova-ti-fol-uje-m). Ako se mijenja po VI. vrsti, analogijom prema glagolima tipa kupovati - kupujem oduzima mu se dio leksičkoga morfa folov- te se premješta na mjesto tematskoga morfa, a korijen se u tom slučaju svodi na neznačenjski fonemski niz fol-.

Posebno je pitanje u morfološkoj i sintaktičkoj adaptaciji engleskih glagola kategorija glagolskoga vida koja u engleskih glagola nije morfološki izražena. ${ }^{33}$ Filipović zato predlaže model dvostupnjevite adaptacije glagola. ${ }^{34}$ Primarnom adaptacijom, odnosno formiranjem osnovnoga oblika replike, glagolski anglizmi stječu ograničenu sposobnost izražavanja vida i dijele se na glagole kojima se izriče samo svršeni vid, na glagole kojima se izriče samo nesvršeni vid i na dvovidne glagole. Nakon što je replika integrirana u sustav jezika primatelja, započinje sekundarna adaptacija tijekom koje glagolski anglizam može steći vidski parnjak. Većina glagola iz našega korpusa okončala je tek primarnu adaptaciju, što znači da je formiran osnovni oblik replike, a glagoli pripadaju jednoj od triju Filipovićevih vidskih skupina: ili su samo svršeni (anfrendati, sinati, kliknuti, logautati se, loginati se), ili su samo nesvršeni (hejtati, stokati, folovati, vocapati, četati), ili su dvovidni (šerati, linkati, logirati se, rikvestati, atendati, invajtati, apruvati, lajkati, apdejtati, postati, trolati, dilitati, čekirati, kenslati, skrolati). Sekundarnu su adaptaciju zasad prošli rijetki glagolski anglizmi i u tome su procesu prefiksacijom izvedeni njihovi svršeni parnjaci: lajkati - polajkati, izlajkati, guglati - izguglati, zguglati, proguglati, logirati se - ulogirati se, kenslati - skenslati, di-

\footnotetext{
${ }^{32}$ Eugenija Barić, Mijo Lončarić, Dragica Malić, Slavko Pavešić, Mirko Peti, Vesna Zečević i Marija Znika, Hrvatska gramatika (Zagreb: Školska knjiga, 1995), 261-265; Josip Silić i Ivo Pranjković, Gramatika hrvatskoga jezika (Zagreb: Školska knjiga, 2005), 45, 48.

${ }^{33}$ Filipović, Teorija jezika u kontaktu, 140-144; Nikolić-Hoyt, „Hrvatski u dodiru s engleskim jezikom,“196; Ana Mikić Čolić, „Tvorba glagolskih neologizama i uklapanje u jezični sustav,“ Fluminensia: časopis za filološka istraživanja, sv. 27, br. 1 (2015): 91-94.

${ }^{34}$ Filipović, Teorija jezika u kontaktu, 141.
} 
litati $-z$ dilitati. Nekoliko je studenata u anketi navelo vidske parnjake glagolima čekirati (pročekirati), trolati (strolati) i skrolati (odskrolati). Jedini svršeni glagol kojemu je vidski parnjak izveden sufiksalnom tvorbom jest glagol kliknuti; nesvršeni mu je parnjak glagol klikati. Čak se i malim korpusom naših primjera može potvrditi tendencija povećanja broja dvovidnih glagola u hrvatskome jeziku pod utjecajem posuđenica iz engleskoga jezika. ${ }^{35}$ Ana Mikić Čolić pretpostavlja da bi krajnji ishod te tendencije bilo ,jačanje kategorije dvovidnih glagola, što bi značilo da je došlo do izravnog utjecaja jezičnog posuđivanja na hrvatski gramatički sustav". ${ }^{36}$ Valja međutim primijetiti da se frekventnijim glagolskim posuđenicama koje uđu u aktivnu uporabu deriviraju vidski parnjaci, ${ }^{37}$ pa bi svakom glagolskom neologizmu, koji prema logici vremenskoga raslojavanja leksika provodi određeni period u prijelaznome leksičkom sloju, ${ }^{38}$ valjalo dati priliku da ga jezična zajednica evaluira, prihvati i omogući mu ulazak u aktivnu uporabu. Tada se otvara mogućnost za sekundarnu adaptaciju u kojoj postojeći dvovidni glagol obično zadržava nesvršeni vid (lajkati, guglati, logirati se, kenslati, dilitati), a prefiksacijom mu se izvodi svršeni parnjak ( $p o-$ lajkati, izlajkati, izguglati, zguglati, proguglati, ulogirati se, skenslati, $z$ dilitati). Događa se to i većini glagola sa sufiksom -ira-ti koji se u hrvatskim gramatikama redovito navode kao primjeri dvovidnih glagola iako su im govornici osmislili vidske parnjake: tuširati se - istuširati se, koncentrirati se - skoncentrirati se, operirati - izoperirati, telefonirati - istelefonirati, dirigirati - izdirigirati, lakirati - polakirati, citirati - iscitirati, definirati - izdefinirati, razminirati - razminiravati itd. Slični se perfektivizacijski postupci provode i u nekih glagola koji nemaju sufiks -ira-ti: ručati - poručati, večerati - povečerati, vjenčat $i$ se - povjenčati se, čestitati - počestitati itd. Time se samo potvrđuje da je vid hrvatskomu glagolu inherentna gramatička kategorija ${ }^{39}$ i da govornici hrvatskoga intuitivno teže izvođenju vidskih parnjaka dvovidnim glagolima.

\footnotetext{
${ }^{35}$ Filipović, Teorija jezika u kontaktu, 143-144.

${ }^{36}$ Mikić Čolić, „Tvorba glagolskih neologizama,“ 93.

${ }^{37}$ Registriranje u rječniku najautoritativnija je potvrda ulaska glagolskih neologizama u aktivnu uporabu. U VRH-u je zabilježeno šest glagola iz našega korpusa: čekirati, guglati, kliknuti, lajkati, logirati se, skrolati; potonji u obliku skrolirati. Svim tim glagolima studenti su u anketi naveli vidske parnjake. Valja napomenuti da je glagolu čekirati u VRH-u navedeno samo jedno značenje, 'obaviti/obavljati čeking', a čeking se definira kao 'pregled i provjera putnika i prtljage prije ulaska u avion'.

${ }^{38}$ Samardžija, Hrvatski jezik 4, 31-32.

${ }^{39}$ Marković, Uvod u jezičnu morfologiju, 183.
} 
Što se tiče semantičke prilagodbe glagola iz našega korpusa, načelno se može primijetiti da većina hrvatskih replika preuzima samo jedno značenje polisemnoga engleskog modela, i to ono vezano za internet i elektroničku komunikaciju (šerati, linkati, rikvestati, atendati, invajtati, stokati, sinati, folovati, postati, čekirati, četati). ${ }^{40}$ To znači da u njih dolazi do primarne semantičke adaptacije, odnosno do suženja broja značenja. Neke hrvatske replike imaju dva značenja (kliknuti, lajkati, kenslati) i ponovno su primjer suženja broja značenja jer engleski modeli imaju više od tih dvaju značenja. Jedina replika s dvama značenjima ekvivalentnima dvama značenjima engleskoga modela glagol je apdejtati, što znači da prolazi nultu semantičku adaptaciju, kao i monosemni glagoli anfrendati, logautati se, odlogirati se, ulogirati se, loginati se, guglati, skrolati. Primjere suženja polja značenja nalazimo u glagola apruvati, hejtati, dilitati.

Posebno su zanimljiva dva glagola koja se dekomponiraju, odnosno rastavljaju na glagolski dio (u obama je to slučajevima glagol baciti sa značenjem 'uputiti') i na imenski dio (glagolsku imenicu suptrakcijom tvorenu od dekomponiranih glagola). Riječ je o glagolima hejtati i sinati/ seenati i njihovim perifrazama baciti hejt i baciti seen/sin. Dekomponiranje donosi određeni značenjski pomak i afektivnost: glagol hejtati znači 'ne simpatizirati koga', a baciti hejt 'uvrijediti koga, dobaciti komu što uvredljivo'; glagol sinati/seenati primarno znači 'vidjeti poruku', a baciti seen znači 'vidjeti poruku i uskratiti odgovor', što podrazumijeva ignoriranje sugovornika jer servisi za trenutačnu razmjenu poruka obavještavaju korisnika da je njegov adresat vidio poruku.

U mojoj se uvodnoj priči pojavljuju dvije imeničke posuđenice, lajk 'oblik iskazivanja odobravanja koga ili čega ili slaganja s kime u čemu pritiskom na za to predviđeno mjesto na društvenim mrežama' i post 'tekst koji korisnik objavljuje na internetu'. Obje su zabilježene u VRH-u odakle su preuzete definicije njihovih značenja. Osim tih dviju imenica studenti su u anketi naveli i ove: selfi 'autoportret snimljen pametnim telefonom', hejter 'onaj koji piše uvredljive i negativne komentare na internetu; onaj koji ni o čemu i ni o kome ne govori pozitivno', folov 'broj pratitelja na društvenoj mreži, najčešće na Instagramu', folover 'pratitelj na društvenoj mreži', vju 'pregled videozapisa na Youtubeu', influenser 'osoba koja na društvenim mrežama ima mnogo sljedbenika i svojim objavama (ob. reklamama određenih proizvoda i usluga) utječe

\footnotetext{
${ }^{40}$ Pri utvrđivanju stupnja transsemantizacije značenja hrvatskih replika uspoređivana su sa značenjem engleskih modela opisanih u on-line rječniku engleskoga jezika Cambridge Dictionary (https://dictionary.cambridge.org/).
} 
na ciljanu skupinu ljudi', tred 'niz povezanih objava različitih korisnika interneta u kojima se raspravlja o određenoj temi', skrinšot, printskrin 'fotografija računalnog zaslona'.

\section{Tvorba kratica}

Ortografske inovacije na društvenim mrežama mogu se lako dešifrirati i uglavnom su svedive na odbacivanje normativnih uzusa koji se odnose na kapitalizaciju, punktuaciju, razmake ili bjeline, dijakritičke znakove i kratice. To ne znači da interpunkcijskih znakova, ${ }^{41}$ velikih početnih slova, ${ }^{42}$ bjelina i dijakritičkih znakova uopće nema, nego da se prenamjenjuju i pojavljuju drukčijom logikom od one propisane ortografskom normom. Ukratko, riječ je o postupcima koje Krešimir

\footnotetext{
${ }^{41}$ Interpunkcijski i pravopisni znakovi imaju doista raznovrsnu uporabu na društvenim mrežama i u internetskome diskursu uopće. Crystal (Internet Linguistics, 62-63) primjerice ilustrira raširenost uporabe uskličnika u internetskome diskursu nizom raznovrsnih značenja koja taj znak nosi. To su između ostaloga poticaj (Čitajte e-knjige!), isprika (Oprosti!), izazov (Dokaži!), slaganje ili podrška (U pravu si!), izjava ili tvrdnja (Od toga mi je počela ispadati kosa!), mišljenje (Sviđa mi se!), prijateljski pozdrav i dobra želja (Bok! Sretno!), izrazi iritiranosti, nepristojnosti i neprijateljstva (Ne može! Idiot! Odjebi!), smanjivanje napetosti (Smiri se!), sarkastična opaska (Jako pametno!), zahvalnost (Puno ti hvala!). I upitnik ima svoje polje uporabe, pa se gotovo redovito nalazi na kraju upitne rečenice, a umnožavanje i upitnika i uskličnika intenzivira temeljni afekt iskaza (Molim?!?!?!, Što si rekao???). Katkada se pitanje ili zbunjenost, iznenađenje i zaprepaštenje, kao i niz drugih intenzivnih osjećaja iskazuje samo multipliciranjem upitnika i uskličnika. Tomu valja dodati da običaj izostavljanja točke na kraju rečenice samo potvrđuje njezinu izjavnost, dok se nedovršenost iskaza i različita emotivna stanja signaliziraju trotočkom. Neki pravopisni znakovi koji su prije pojave interneta bili posve marginalni postaju iznimno zauzeti na društvenim mrežama (npr. znak \#, ljestve, hešteg, engl. hashtag; znak *), a i sami su emotikoni nastali kombinacijom različitih pravopisnih znakova. Dakle ne može se tvrditi da interpunkcijskih i pravopisnih znakova u komunikaciji na društvenim mrežama nema, nego da je njihova namjena drukčija u odnosu na onu koju propisuje ortografska norma.

${ }^{42}$ Velika početna slova automatski se pojavljuju u mnogim aplikacijama za trenutačnu razmjenu poruka nakon točke, upitnika, uskličnika. Neki korisnici namjerno isključuju tu postavku jer internetska komunikacija uopće - pa tako i komunikacija na društvenim mrežama - nije osjetljiva na kapitalizaciju. Poseban je slučaj pisanje verzalom: pravila netiquettea (engl. 'pravila korektnoga i prihvatljivoga komuniciranja na internetu') nalažu izbjegavanje takve prakse jer se doživljava kao vikanje. No verzal može biti dio složenih grafostilema i izvrstan intenzifikator ako se promišljeno dozira (npr. tako može biti napisana samo jedna riječ u rečenici (Sviđa mi se JAKO) ili prefiks u izvedenici (PREkraljica)). Stoga ponovno valja naglasiti da verzal i velika početna slova nisu nestali iz komunikacije na društvenim mrežama, nego su prenamijenjeni. Usp. Rebeka Holjevac, „Grafostilistika digitalnog diskursa“" (diplomski rad, Filozofski fakultet Sveučilišta u Zagrebu, 2017, pristupljeno 15. siječnja 2020, http://www.stilistika.org/studentski-kutak/diplomski-radovi/247-grafostilistika-digitalnog-diskursa).
} 
Bagić naziva figurama zapisa ili pravopisnim figurama i definira ih kao upotrebu pravopisnih znakova ,slobodnu od logičkih, gramatičkih i inih pravila konkretnoga jezičnog sustava“" ${ }^{43}$ Vrlo pojednostavljeno tumačenje tako reducirana i subvertirana pravopisa zasniva se na zaključcima da su korisnici društvenih mreža neobrazovani te da ne poznaju osnove ortografske norme i nemaju namjeru da se educiraju, što daje posla jezičnim savjetodavcima koji ih prekoravaju, revno popisuju sve njihove ortografske grijehe strogo ih omjeravajući o standardnojezične zakone te iznose zastrašujuće prognoze o padu pismenosti i jezične kompetencije uopće. ${ }^{44}$ Crystal ističe da na preosmišljavanje pravopisa na internetu utječu mnogi čimbenici te da ono nije uzrokovano isključivo neobrazovanošću korisnikâ toga medija. ${ }^{45}$ Budući da se s pojavom interneta razvija posve nov funkcionalni stil hrvatskoga jezika, koji su Lada Badurina i Marina Kovačević nazvale multimedijalnim diskursom, ${ }^{46}$ legitimno je i na njega protegnuti tvrdnju Josipa Silića da svaki stil ima svoje zakonitosti koje se iz perspektive nekog drugog stila istoga jezika ne mogu proglašavati pogreškama ${ }^{47}$ Stoga je ispitivanje semantičke i pragmatičke funkcije ortografskih inovacija na društvenim mrežama mnogo smisleniji istraživački zadatak nego prebrojavanje i popisivanje postupaka koji odudaraju od službenoga pravopisa. U ovome ćemo se poglavlju usredotočiti na vrlo produktivan ortografski postupak u komunikaciji na servisima za trenutačnu razmjenu poruka koji ima konkretnu funkciju i lako uočljive mehanizme. Riječ je o tvorbi jednostavnih kratica (abrevijacija) i složenih kratica (akronima). Njihova frekventnost $u$ polju društvenih mreža posljedica je osnovnoga načela tvorbe tih jedinica uopće, a to je ekonomičnost: „riječi se skraćuju radi uštede prostora“" ${ }^{48} \mathrm{U}$ vezi s aplikacijama za trenutačnu razmjenu poruka

${ }^{43}$ Krešimir Bagić, Živi jezici. Poetska pisma Ivana Slamniga, Josipa Severa i Anke Žagar (Zagreb: Naklada MD, 1994), 31.

${ }^{44}$ Vidi npr. tekst Maje Hrgović „Lajkamo, hejtamo i degradiramo hrvatski jezik,“ Novi list, 6. siječnja 2013, pristupljeno 22. prosinca 2019, http://www.novilist.hr/Kultura/Ostalo/ Lajkamo-hejtamo-i-degradiramo-hrvatski-jezik.

${ }^{45}$ Crystal, Internet Linguistics, 62. Neobrazovanost korisnika interneta samo je jedan mogući razlog odbacivanja normativnih ortografskih načela u komunikaciji na društvenim mrežama. Korisnici mogu veoma suvereno vladati ortografskim pravilima, ali ih na društvenim mrežama svjesno ne žele primjenjivati jer slijede prešutno uspostavljenu ortografsku anarhiju u tome komunikacijskom polju (usp. Holjevac, „Grafostilistika digitalnog diskursa“).

${ }^{46}$ Lada Badurina i Marina Kovačević, Raslojavanje jezične stvarnosti (Rijeka: Izdavački centar Rijeka, 2001).

${ }^{47}$ Josip Silić, Funkcionalni stilovi hrvatskoga jezika (Zagreb: Disput, 2006).

${ }^{48}$ Lada Badurina, Ivan Marković i Krešimir Mićanović, Hrvatski pravopis (Zagreb: Matica hrvatska, 2007), 179. 
valja naglasiti da se riječi skraćuju i radi uštede vremena jer se poruke razmjenjuju u realnome vremenu imitirajući usmenu komunikaciju, pa se takav razgovor odvija na granici između pisanoga i govorenoga plana jezične realizacije. ${ }^{49}$ Mali ekrani i male tipkovnice dodatni su razlozi zbog kojih se u porukama pisanima na pametnim telefonima skraćivanje riječi i višečlanih izraza nameće kao postupak važniji nego u porukama pisanima na računalu i obično je posljedica nužnosti, a ne isključivo ludičkih impulsa. ${ }^{50}$ Bagić ističe da akronimijom ,više ravna izražajna lakoća i ekonomičnost nego figurativnost" ${ }^{\text {"51 }}$ Dakle kratice su se, kao i mnogi drugi ortografski i grafološki postupci, pojavile u promatranome mediju komunikacije i zbog tehničkih ograničenja koja taj medij nameće..$^{52}$

Dok su leksičke jedinice nastale rječotvornim postupcima opisanima u prethodnome poglavlju - neosemantizmom i leksičkim posuđivanjem - i zapisive i izgovorive, pa se rabe i u pisanoj i u usmenoj komunikaciji, kratice se gotovo isključivo vežu za pisanu komunikaciju na servisima za trenutačnu razmjenu poruka. Crystal ističe da nisu tvorene s namjerom da se naglas izgovaraju, kao ni kemijske formule. ${ }^{53}$ Zato su mehanizmi njihova nastanka vezani za domenu grafoloških taktika, pa ćemo izdvojiti tri najplodnija takva postupka tvorbe hrvatskih kratica vezanih za komunikaciju u spomenutome mediju. $^{54}$

\footnotetext{
${ }^{49}$ Ranko Bugarski, Jezik i kultura (Beograd: Biblioteka XX vek, 2005), 23-24.

${ }^{50}$ Za SMS-poruke važan je čimbenik skraćivanja i ograničen broj znakova u poruci, odnosno činjenica da se prekoračenje toga ograničenja naplaćuje kao nova poruka. Taj je razlog uporabe kratica i najbolja potvrda njihove ekonomičnosti i pragmatičnosti.

${ }^{51}$ Krešimir Bagić, Rječnik stilskih figura (Zagreb: Školska knjiga, 2012), 10.

${ }^{52}$ U Rječniku kratica (Zagreb: Nakladni zavod Globus, 2007) Stjepana Babića i Milene Žic Fuchs nalazi se dodatak „SMS i internetske kratice“ koji obaseže 20 stranica (535-554). Jedna jedina kratica iz hrvatskoga je jezika (AMR 'ako me razumiješ'); sve su ostale iz engleskoga jezika i mnoge se čine posve okazionalnima, odnosno nisu u proteklih trinaest godina ušle $u$ aktivnu uporabu. To je uobičajena sudbina novih jezičnih jedinica $u$ internetskoj komunikaciji: tek će mali broj njih izdržati test vremena i postati dio aktivnoga leksika (David Crystal, Language and the Internet (New York: Cambridge University Press, 2006), 263). Zato ne iznenađuje kratkoročna aktualnost posebnih rječnika u kojima se popisuju nove jezične jedinice (kratice, stopljenice, tuđice itd.). Bagić (Rječnik stilskih figura, 10) ističe da je brojenje akronima ,uzaludan (...) posao, jer svakodnevno nastaje velik broj novih".

${ }^{53}$ David Crystal, Txtng. The Gr8 Db8 (New York: Oxford University Press, 2008), 54.

${ }^{54}$ Kratice uvrštene u ovaj rad prikupljene su anketom o kojoj je već bilo riječi u 16. i 26. fusnoti. Ispitanici su u trećemu dijelu ankete morali navesti sve kratice kojima se služe na servisima za trenutačnu razmjenu poruka (Messenger, WhatsApp, Viber, Snapchat, Skype, Signal).
} 
Prvi je od njih ispuštanje vokala ${ }^{55}$ pri čemu se jedna riječ ili više njih svodi na niz konsonanata, što podsjeća na pismovnu praksu arapskoga ili hebrejskoga jezika. Čini se da su i govornici jezika koji nemaju takvu praksu svjesni toga da konsonanti imaju veći informacijski i značenjski potencijal od vokala jer su brojniji i njihova je kombinacija distinktivnija od kombinacije vokala. ${ }^{56}$ Iz stilističke bi se perspektive o tome grafijskom postupku moglo govoriti kao o avokalskome lipogramu. ${ }^{57}$ Najčešće se vokali izvlače iz konsonantske rešetke jedne riječi: $b z v z$ 'bezveze', $h v l$ 'hvala', $n k d$ 'nikad, nekad', včrs 'večeras', dns 'danas', jčr 'jučer', $k j$ 'kaj', fkt 'fakat', $z h r$ 'ziher', zkj 'zakaj', jbt 'jebote', jbg 'jebiga', tkđr 'također'. Gdjekad se dogodi da se osim svih vokala iz riječi ispusti i pokoji konsonant: $m s m$ 'mislim', obvz 'obavezno'. Potonji primjer pokazuje da se katkada zadržava inicijalni vokal riječi; tako je i u kratici opt 'opet'. Očito je da su i tako suptrahirane i kontrahirane jedinice razumljive u kontekstu, što je osnovno načelo skraćivanja koje intuitivno slijede svi korisnici društvenih mreža i servisa za trenutačnu razmjenu poruka. Ima i primjera ispuštanja vokala iz jedinica većih od riječi, pri čemu prva riječ uvijek izriče negaciju: $n z m$ 'ne znam', $n m g$ 'ne mogu', $n m v z$ 'nema veze', $n n c ̌$ 'nema na čemu'. Jedine dvije engleske kratice nastale ispuštanjem vokala koje su svi studenti naveli u anketi jesu pls 'please' i tnx 'thanks'.

Drugi je način kraćenja clipping, odnosno ispuštanje ili obrezivanje dijelova riječi, što se u promatranome korpusu uglavnom čini na dočetku riječi. ${ }^{58}$ Postupak izostavljanja slovnoga materijala na kraju riječi naziva se apokopom ${ }^{59}$ i u najviše prikupljenih primjera rezultira svođenjem riječi na prva tri slova, koja se očito drže dovoljnima za prepoznavanje cijele riječi u kontekstu. Ovo su najčešći primjeri: odg 'odgovoriti', zab 'zaboraviti', zap 'zapisati', ozb 'ozbiljno', stv 'stvarno', zaš 'zašto', odj 'odjebi', sup 'super', ček 'čekaj', ugl 'uglavnom', neš 'nešto', odl 'odlično', mob 'mobitel', por 'poruka', mis 'mislim'. Neke su riječi svedene samo na prva dva slova ( $t j$ 'tjedan', $v j$ 'vjerojatno'), druge na više od triju (najvj 'najvjerojatnije'). U nekih se kratica geminira završni konsonant: pozz 'pozdrav' (postoji i oblik sa samo jednim

\footnotetext{
${ }^{55}$ Svjesno izbjegavamo termin redukcija samoglasnika zato što se odnosi na slabljenje i gubljenje samoglasnika u govoru. U našim su primjerima oblici nastali ispuštanjem vokala neizgovorivi i realiziraju se isključivo u pisanome tekstu.

${ }^{56}$ Crystal, Language and the Internet, 263; Crystal, Txtng, 26.

${ }^{57}$ Bagić, Rječnik stilskih figura, 182.

${ }_{58}^{58}$ Marković, Uvod u jezičnu morfologiju, 88-89; Crystal, Txtng, 45.

${ }^{59}$ Marković, Uvod u jezičnu morfologiju, 88; Bagić, Rječnik stilskih figura, 58.
} 
završnim konsonantom, poz, ali i oblici u kojima se završni konsonant multiplicira, pozzzz), iss 'isuse', nezz 'ne znam' (jedini primjer apokope dviju riječi koje, doduše, mnogi govornici hrvatskoga pišu sastavljeno). Jedina tri primjera izostavljanja slovnoga materijala na početku riječi očito imaju funkciju eufemizacije: čko 'pičko', rac 'kurac' i pak 'šupak'. Takav se postupak naziva aferezom. ${ }^{60}$

Treći je način nastanka kratica akronimizacija ili inicijalizacija ${ }^{61}$ odnosno bilježenje prvih slova više riječi, zbog čega se tako nastale kratice nazivaju složenima. Od jednostavnih se kratica ili abrevijacija - kojima pripadaju dosad spomenuti primjeri ispuštanja vokala i clippinga - razlikuju po tome što postaju samostalne imenice (NATO, Hina, Fina, Nama i sl.), s gramatičkim kategorijama i fleksijom. Akronimi na društvenim mrežama ne zadovoljavaju kriterij samostalnosti niti nastaju inicijalizacijom vlastitih imena, no Crystal naziva akronimima sve jedinice nastale od početnih slova riječi, bez obzira na to jesu li te riječi vlastita imena, opće imenice, fraze ili pozdravi i bez obzira na to vlada li se tako nastala kratica kao samostalan oblik riječi ili ne vlada. ${ }^{62}$ Štoviše, akronimom naziva i kratice nastale svođenjem jedne jedine riječi na njezin inicijal, za što su primjeri zabilježeni i u našoj anketi: $k$ 'kurac' (obično u frazi koji k?), đ 'đabe', ž! 'živjeli!'. Takve primjere Crystal određuje i kao logograme jer jedan znak (u ovome slučaju slovo) predstavlja cijelu riječ. ${ }^{63}$ Logogrami se od akronima razlikuju po tome što slovo koje predstavlja riječ ne mora biti inicijal, pa je odličan primjer čistoga logograma slovo $x$ sa značenjem 'pusa' i slovo $k$ sa značenjem ' $o k$ ' ${ }^{64}$

Najviše je akronima prikupljenih anketom nastalo od početnih slova fraza, pozdrava, cjelovitih ili eliptiranih rečenica: lp 'lijep pozdrav', In 'laku noć', bmk 'boli me kurac', $b t j$ 'bog te jebo', $m m$ 'moš mislit', $t j t$ 'to je to', $k t b k$ 'kaj te boli kurac', $d c$, dct 'di si, di si ti' (konsonanti se izgovaraju kao da se sriču na engleskome jeziku). U odnosu na samo dvije engleske kratice nastale ispuštanjem vokala koje su studenti naveli $\mathrm{u}$ anketnome upitniku engleske kratice nastale akronimizacijom mnogo su uobičajenije i frekventnije. Navodimo one koje je u svojoj komunikaciji na servisima za trenutačnu razmjenu poruka potvrdilo najmanje 70

\footnotetext{
${ }^{60}$ Marković, Uvod u jezičnu morfologiju, 88; Bagić, Rječnik stilskih figura, 7.

${ }^{61}$ Crystal, Txtng, 41.

${ }^{62}$ Crystal, Txtng, 41-42.

${ }^{63}$ Crystal, Txtng, 37-38.

${ }^{64}$ Usp. Lea Palinić, „Žargon zagrebačke mladeži i komunikacija putem alata za Instant Messaging“ (diplomski rad, Filozofski fakultet Sveučilišta u Zagrebu, 2019).
} 
od 100 studenata: omg 'oh my good', wtf 'what the fuck', lol 'laugh out loud', btw 'by the way', asap 'as soon as possible', yolo 'you only live once', cy 'see ya', cu 'see you', ly 'love you', lysm 'love you so much', ty 'thank you', brb 'be right back'.

Neke kratice nastaju kombinacijom dvaju postupaka. Ispuštanjem vokala i akronimizacijom nastala je kratica $n m p$ 'nemam pojma', kombinacijom ispuštanja vokala i apokope oblikovana je kratica vjv 'vjerovatno/ vjerojatno', a kombinacijom ispuštanja vokala i afereze kratica $b g b g$ 'jeba ga bog'. Kombinacija slova i brojke česta je u razmjeni poruka na engleskome jeziku ( $y 2$ 'you too', $H 8$ 'heit', $d 8$ 'date', $b 4$ 'before' i sl.); u hrvatskome su takve kombinacije rijetke i među primjerima prikupljenima anketiranjem studenata zabilježene su samo dvije (5ak 'petak', $5 b, 10 b$ 'pet banki, deset banki'). ${ }^{65}$ Kratice nastale kombinacijom slova i brojke Crystal naziva rebusima koji kao način skraćivanja i šifriranja iskaza postoje od antike, a sámo se načelo uporabe različitih znakova koji predstavljaju glasove može povezati i s logikom oblikovanja egipatskih hijeroglifa. ${ }^{66}$ Stoga kraćenje u današnjim porukama koje se razmjenjuju putem servisa poput Messengera nije nikakva novina, nego nastavak duge ludičke jezične tradicije koju mnogi korisnici društvenih mreža nesvjesno nastavljaju u novim medijima.

Koliko je kraćenje plodan postupak redukcije u porukama koje se razmjenjuju u realnome vremenu, pokazuje i pojava kratične homonimije. Naime u homonimni odnos mogu ući kratice tvorene različitim i istim postupcima kraćenja. Kratica $n k d$ nastala ispuštanjem vokala može značiti i 'nekad' i 'nikad', a kratica $d$ ns može nastati i ispuštanjem vokala (tada znači 'danas') i akronimizacijom (tada znači 'daj ne seri').

Uporabu svih dosad spomenutih kratica - osim onih koje su istaknute kao kurioziteti - potvrdilo je minimalno 70 od 100 anketiranih studenata; to je bio uvjet za uvrštavanje kratica u ovaj rad i osnova za isticanje mehanizama kojima se one tvore. Uporabu nekih kratica potvrdili su svi ispitani studenti, npr. sve avokalske lipograme nastale od jedne riječi, kao i većinu troslovnih kratica nastalih apokopom (odg 'odgovoriti', zab 'zaboraviti', ozb 'ozbiljno', zaš 'zašto', odj 'odjebi', ček 'čekaj', ugl 'uglavnom', neš 'nešto', odl 'odlično', mob 'mobitel', pozl pozz 'pozdrav') i većinu složenih kratica nastalih akronimizacijom (lp 'lijep pozdrav', In 'laku noć', $b m k$ 'boli me kurac', $m m$ 'moš mislit', $d c$, $d c t$ 'di si, di si ti'). Dakle te kratice aktivno rabe studenti Filozofskoga

${ }^{65}$ Usp. Palinić, „Žargon zagrebačke mladeži“.

${ }^{66}$ Crystal, Internet Linguistics, 5; Crystal, Txtng, 39-41. 
fakulteta rođeni između 1996. i 2000. i njihovi vršnjaci. Za nekoliko kratica koje nemaju stopostotnu potvrdu (npr. sup 'super', čko 'pičko', rac 'kurac' i pak 'šupak') neki su mi studenti nakon predaje ispunjenih anketnih upitnika naglasili da su ih koristili dok su bili mlađi i da im se sada čine infantilnima. Distanciranje od određenih jezičnih praksi u komunikaciji na društvenim mrežama pokazatelj je postojanja niza generacijskih, profesionalnih, stručnih, političkih i inih žargona u tome mediju komunikacije. ${ }^{67}$ Neki od tih žargona nastaju - između ostaloga - i zbog kodiranja nekih jezičnih jedinica koje omogućuju šifriranje komunikacije, odnosno jamče njezinu razumljivost samo onima koji pripadaju izabranoj grupi. ${ }^{68}$ Stoga ne iznenađuje činjenica da su anketom prikupljene neke kratice koje su poznate tek manjemu broju studenata, i to zato što su tvorene okazionalno i plod su jezične igre koja je slučajno postala komunikacijska manira neke zatvorene grupe ili zato što su pomno šifrirane da bi maskirale kompromitirajuće sadržaje (npr. $s p$ 'samo prirodno', iup 'idemo u prirodu' i inf 'idemo na frulu' kratice su za pušenje marihuane i zabilježene su samo u jednome anketnom upitniku). ${ }^{69}$

\section{Strahujući od mrežogovora}

Crystal ističe da je jedna od uobičajenih konvencija kojima počinju ili završavaju tekstovi o jeziku na internetu upozoravanje čitatelja na prolaznost i kratkotrajnost svih u tekstu opisanih gramatičkih, grafoloških, ortografskih, semantičkih i diskursnih praksi. ${ }^{70}$ Autori takvih tekstova ograđuju se od jasne procjene raširenosti inovativnih jezičnih postupaka koje opisuju, ne usuđuju se nagađati koliko će dugo trajati ni kakav je njihov uporabni status na razini cijele jezične zajednice, ne uopćuju rezultate svojih istraživanja u jasno artikulirana obilježja jezika na internetu i opravdavaju svoju suzdržanost munjevitim razvojem tehnologije koji ne dopušta nikakve rezolutne zaključke ni dugoročne prognoze o razvoju jezika na internetu. Internet nije homogen jezični medij, nego skup raznovrsnih žanrova, stilova, registara i varijeteta; ${ }^{71}$

\footnotetext{
${ }^{67}$ Crystal, Txtng, 22.

${ }^{68}$ Crystal, Txtng, 56-57.

${ }^{69} \mathrm{O}$ različitim načinima šifriranja riječi koje se odnose na opojna sredstva usp. Palinić, „Žargon zagrebačke mladeži“.

${ }^{70}$ Crystal, Language and the Internet, 257.

${ }^{71}$ Crystal, Language and the Internet, 271.
} 
internet je u tome smislu samo jedan od medija u kojemu se komunicira na različite načine, pa nije potrebno unificirati jezik koji opslužuje tako širok raspon komunikacijskih potreba. U ovome smo se radu nastojali usredotočiti na samo jednu vrstu internetskoga servisa koji korisnicima omogućuje komunikaciju i povezivanje, na samo jednu zajednicu prakse koja nam je priskrbila korpus i na samo tri rječotvorna postupka kojima se popunjavaju leksičke praznine u tome komunikacijskom polju. Dakle bavili smo se komunikacijom na društvenim mrežama, i to ponajprije na Facebooku, te na servisima za trenutačnu razmjenu poruka; korpus smo prikupili među studentima Kroatistike Filozofskoga fakulteta u Zagrebu akademske godine 2018/2019; opisali smo nove leksičke jedinice tvorene neosemantizmom, leksičkim posuđivanjem i različitim vrstama kraćenja. Budući da su svi neokazionalni (i neki okazionalni) primjeri tako definiranih jezičnih inovacija stali u ovaj rad, nema razloga za bojazan da će „mrežogovor“ izazvati goleme jezične promjene i poremećaje u ljudskoj komunikaciji. Naprotiv, ugradit će još jednu vrijednost u obilježje standardnoga jezika koje zovemo polifunkcionalnošću.

\section{Literatura}

Anić, Vladimir. Veliki rječnik hrvatskoga jezika. Posebno izdanje. Priredila Ljiljana Jojić. Zagreb: Novi Liber, 2005.

Babić, Stjepan, i Milena Žic Fuchs. Rječnik kratica. Zagreb: Nakladni zavod Globus, 2007.

Badurina, Lada, i Marina Kovačević. Raslojavanje jezične stvarnosti. Rijeka: Izdavački centar Rijeka, 2001.

Badurina, Lada, Ivan Marković, i Krešimir Mićanović. Hrvatski pravopis. Zagreb: Matica hrvatska, 2007.

Bagić, Krešimir. Živi jezici. Poetska pisma Ivana Slamniga, Josipa Severa i Anke Žagar. Zagreb: Naklada MD, 1994.

Bagić, Krešimir. Rječnik stilskih figura. Zagreb: Školska knjiga, 2012.

Barić, Eugenija, Mijo Lončarić, Dragica Malić, Slavko Pavešić, Mirko Peti, Vesna Zečević, i Marija Znika. Hrvatska gramatika. Zagreb: Školska knjiga, 1995.

Bugarski, Ranko. Jezik i kultura. Beograd: Biblioteka XX vek, 2005.

Cambridge Dictionary. Pristupljeno 28. siječnja 2020. https://dictionary.cambridge. org/.

Crystal, David. A Glossary of Netspeak and Textspeak. Edinburgh: Edinburgh University Press, 2004.

Crystal, David. Language and the Internet. Second Edition. New York: Cambridge University Press, 2006.

Crystal, David. Txtng. The Gr8 Db8. New York: Oxford University Press, 2008. 
Crystal, David. Internet Linguistics: A Student Guide. London - New York: Routledge, 2011.

Filipović, Rudolf. Teorija jezika u kontaktu. Uvod u lingvistiku jezičnih dodira. Zagreb: Jugoslavenska akademija znanosti i umjetnosti - Školska knjiga, 1986.

Filipović, Rudolf. Anglicizmi u hrvatskom ili srpskom jeziku: porijeklo, razvoj, značenje. Zagreb: Jugoslavenska akademija znanosti i umjetnosti - Školska knjiga, 1990.

Görlach, Manfred. English in Europe. Oxford: Oxford University Press, 2002.

Hadžiahmetović Jurida, Sanel. „Some distinctive lexical features of Netspeak.“ Jezikoslovlje, sv. 8, br. 2 (2007): 193-210.

Hadžiahmetović Jurida, Sanel. „The language of information technology: Figurative use of computer terms.“ Jezikoslovlje, sv. 17, br. 3 (2016): 557-574.

Holjevac, Rebeka. „Grafostilistika digitalnog diskursa.“ Diplomski rad, Filozofski fakultet Sveučilišta u Zagrebu, 2017. Pristupljeno 15. siječnja 2020. http:// www.stilistika.org/studentski-kutak/diplomski-radovi/247-grafostilistika-digitalnog-diskursa.

Hrgović, Maja. „Lajkamo, hejtamo i degradiramo hrvatski jezik.“ Novi list, 6. siječnja 2013. Pristupljeno 22. prosinca 2019. http://www.novilist.hr/Kultura/ Ostalo/Lajkamo-hejtamo-i-degradiramo-hrvatski-jezik.

Hrvatski jezični portal. Pristupljeno 28. siječnja 2020. http://hjp.znanje.hr/index. php?show=main.

Marković, Ivan. Uvod u jezičnu morfologiju. Drugo izdanje. Zagreb: Disput, 2013.

Mikić Čolić, Ana. „Tvorba glagolskih neologizama i uklapanje u jezični sustav.“ Fluminensia: časopis za filološka istraživanja, sv. 27, br. 1 (2015): 87-102.

Nikolić-Hoyt, Anja. „Hrvatski u dodiru s engleskim jezikom.“ U Hrvatski jezik u dodiru s europskim jezicima: prilagodba posuđenica Lelije Sočanac, Orsolye Žagar-Szentesi, Dragice Dragičević, Ljube Dabo-Denegri, Antice Menac i Anje Nikolić-Hoyt, 179-219. Zagreb: Nakladni zavod Globus, 2005.

Palacios Martínez, Ignacio M., i José A. Sánchez Fajardo. „Introduction: Gaining Insights into English as a Contact Language and Its Diffusion.“ Alicante Journal of English Studies, sv. 30 (2017): 5-22.

Palinić, Lea. „Žargon zagrebačke mladeži i komunikacija putem alata za Instant Messaging.“ Diplomski rad, Filozofski fakultet Sveučilišta u Zagrebu, 2019.

Redli, Jelena. „Inovacije u jeziku mladih na društvenim mrežama.“ ResearchGate (2018). Pristupljeno 7. studenog 2019. https://www.researchgate.net/publication/329587163_INOVACIJE_U_JEZIKU_MLADIH_NA_DRUSTVENIM_MREZAMA.

Riggs, Fred W. „Terminology and Lexicography: Their Complementarity.“ International Journal of Lexicography, sv. 2, br. 2 (1989): 89-110.

Samardžija, Marko. Hrvatski jezik 4. Zagreb: Školska knjiga, 2001.

Seargeant, Philip, i Caroline Tagg, ur. The Language of Social Media: Identity and Community on the Internet. London: Palgrave Macmillan, 2014.

Seargeant, Philip, i Caroline Tagg. „The Language of Social Media: Introduction.“ U The Language of Social Media: Identity and Community on the Internet, 1-20. London: Palgrave Macmillan, 2014. 
Silić, Josip. Funkcionalni stilovi hrvatskoga jezika. Zagreb: Disput, 2006.

Silić, Josip, i Ivo Pranjković. Gramatika hrvatskoga jezika. Zagreb: Školska knjiga, 2005.

Turk, Marija. „Razumljivost i stilske značajke kalkova.“ Fluminensia, sv. 15, br. 1 (2003): 9-24.

Vatvedt Fjeld, Ruth, i Lars Nygaard. „Lexical Neography in Modern Norwegian.“ U Exploring Newspaper Language. Using the Web to Create and Investigate a Large Corpus of Modern Norwegian, uredio Gisle Andersen, 221-240. Amsterdam - Philadelphia: John Benjamins Publishing Company, 2012. Veliki rječnik hrvatskoga standardnog jezika. Zagreb: Školska knjiga, 2015. Zgusta, Ladislav. Priručnik leksikografije. Sarajevo: Svjetlost, 1991.

\section{Croatian Word Formation on Social Networks}

Summary: Since the first decade of the 21 st century, when social networks have become a part of everyday life, socially-oriented activities of Internet users have been on the continual rise. By creating a profile on social networks, Internet users cease to be passive Internet content and information consumers, but rather turn into creators, who shape a dynamic space of new media by virtue of their activities and personal contribution. One of the most significant areas in which social network users introduce numerous changes and innovative contents is most certainly communication and language practices. Each and every social network most often ground their recognizability on a fixed set of communication genres available to their members and in that way determine how the members are going to communicate with each other. This has made all the polyfunctional languages, Croatian among them, respond with a rather swift expansion of the existing vocabulary. In my paper, I will be presenting most productive word formation methods in which Croatian language makes up for social networks lexical gaps and shapes the communication style on social networks and instant messaging services. The first is a semantic loan from the English or neosemanticism word formation (e.g. profil, prijatelj, status, zid, dodati, blokirati, notifikacija); the second is a lexical loan word (e.g. lajkati, postati, šerati, atendati, hejtati, trolati, folover, selfi), and the third is creation of abbreviations (pozz, nezz, bmk, jbt, dns, fkt). Emergence of this new and abundant lexical layer in Croatian language requires from us to register a number of new entry units in general dictionaries of Croatian language.

Keywords: neosemanticism, lexical loan words, abbreviations, social networks, instant messaging services 